\title{
The void and the memory. Ludovico Quaroni's competition project for the Tobacco Manufacturing and the Navile Park in Bologna (1984). An urban figurative regeneration
}

\author{
Matteo Sintini \\ University of Bologna, Italy | Department of Architecture \\ matteo.sintini4@unibo.it
}

\begin{abstract}
The Ludovico Quaroni's competition winner project for the urban park of the Tobacco Manufacturing and the Navile dockyard, although unrealised, still represents a sort of conclusive point of the search path (he died in 1987) of one of the most prominent characters of the Italian architectural scene - and not only - of the 20th century. Furthermore, the high number of contenders to the competition's first stage (139) made the contest itself an extraordinary occasion of rethinking an important part of the city of Bologna, a somewhat hybrid part located on the verge of town historic centre and its first expansion and offered the chance of challenge for the mostly Italian architects. The Quaroni's group was composed by many others architects including important authors of the reconstruction projects of Bologna in the years following World War II; their proposal aimed at bringing order in a non-connected urban context filled with many fragments of historical memories of the site. The process of spaces redefinition, as in the beginning projects of the architect's career, is conducted with the tools of the "design" (as used by Manfredo Tafuri, 1964), as an instrument of territorial and urban areas recomposition, undertook through the conservation of trails, overlapped by a new system of episodes, keeping the idea of fragments, responding to the competition requirements. In fact, the project balances the new parts in strict relation with the pre-existing elements of the historic town centre, considering the tangible and material dimensions of the city. Such a new system is governed by a clear scheme of structured elements based on the project of void, provided with a clear formal image, whose final outcome is a figurative regeneration. In this idea and formal organism Quaroni developing many of his design principles, gives a personal interpretation to the contemporary issue of regeneration empowered by those reflections that had just entered in the much wider debate in the mid-eighties, about conservation and sustainability of historic centres and the natural environment. Notably, this issue is dealt with in a cultural environment such as the one of Bologna, a city that gave much to the debate on conservation of old towns (see the Cervellati plan); a discussion founding the Italian experience of the 20th century and particularly of its second half. From this point of view, the contribution of architects from Bologna at Quaroni's project has therefore probably accounted for the special sensibility shown by the project on those matters. After giving up on Quaroni's plan Aldo Rossi was chosen by the Municipality to develop the project; his ideas confirm, although with different outcomes, an approach based on the value of the conservation of memory and the use of clear forms as means of urban regeneration.
\end{abstract}

Keywords: public spaces system; urban design; management plan; enhancement of cultural heritage; historic urban landscape.

\section{To cite this article:}

Sintini M. (2017). The void and the memory. Ludovico Quaroni's competition project for the Tobacco Manufacturing and the Navile Park in Bologna (1984). An urban figurative regeneration. The Journal of Public Space, 2(I), 8I-94, DOI: 10.5204/jps.v2il.52

This article has been peer-reviewed and accepted for publication in The Journal of Public Space. Please see the Editorial Policies under the 'About' section of the journal website for further information. 
The project for the urban area of the Tobacco Manufacturing and of the Navile Park in Bologna is one of the latest works of Ludovico Quaroni', who has notably developed much of his final activities in this city².

Paolo Portoghesi considers the project as the proof of "an unpredictable second youth" (Vincenzi, Veggetti, Zanna, 1985: II) 3 while Giuseppe Ciorra underlines how it is part of a review process of "self-recognition"; either way the project seems to be an overhaul of the use of historical forms that Portoghesi himself sees as successfully deployed both in the project in object and also in the competition for the Opera of Rome (1983), his other coeval important work.

At the appearance of these projects, the architectural criticism focused on the postmodern or post-ancient (Ciorra, 1989: 57) nature of Quaroni's latest works, though there is no intention to participate in the debate on style, rather a will to continue the exploration concerning the universality of forms and the rethinking of the concept of "monumentality". After those remarks, once the area of the competition is rebuilt, reconsidering the project of the Tobacco Manufacturing and of the Navile Park helps in unpacking how the complexity of the interpretation of Quaroni's thoughts is overlapped with the difficulty that architecture faced, at that time, in finding solutions ${ }^{4}$ for the issues brought up by new urban contexts. Based on the correspondence between the author's work and Italian architecture development on the base of Tafuri's book (1964), this reading allows for interpretation of some of the themes from a period that still lacks a definitive verdict from historiography, from the point of view of the final production of a key personality of the 20th century Italian architecture.

At the other hand, it can also see an inverse relationship that explain some contradictory aspects of Quaroni's productions, that define his singularity in the architecture scene also recognisable in the project for Bologna, as the effect of the transition of the mid-eighties. In fact, the architect's continuous research on method based on the "systematic doubt" (Dal Co, 1987: 15), applied on the themes that emerged at the end of the Seventies, show the evolution of some argument of the previous decades, in particular, in this case, it refers to the strategies of urban renewal based on the strengthening of the residential and cultural vocation of the historical centres against the directional functions, strictly connected to environmental issues and energy saving after the second oil crisis.

For these matters and for the large participation of many of the main architects of the moment, the competition represents an important event to measure the development of the Italian architectural culture of the project and the role of the "last" Quaroni in this context.

The competition area lay at the margin of the city located inside the 16th century city walls, of which a small part remains. Far from the traditional image of the Bologna city centre, this zone more closely resembled the idea of suburb due to the fragmentation caused by urbanisation resulting of multiple layers stratified over the centuries, none of which significant enough to strongly inspire the new project.

In the Middle Age the area was vastly crowded by monasteries - mostly destroyed by Napoleon's edicts - and by green areas - some of those still existing - located inside backyards or in interstitial spots close to the city walls.

Furthermore, the area hosts important presences of the historical city system of water; it is crossed by the Cavaticcio canal and by the Navile creek, opened in the I2th century, that could be sailed to reach Ferrara and the Adriatic basin. The natural environment was also conditioned by this presence of water, which encouraged the birth of many hydraulic 
plants. Inside the city walls connected to existence of this important canal, Vignola built a city harbour in 1589, which was later buried according to the Regulatory Plan of 1889; some of whose buildings can still be seen such as: the bakeries, the former Slaughterhouse and the Salt Warehouse along Via Pietramellara. In addition to this, the productive vocation of the area was notably increased at the beginning of the 19th century with the realisation of the Tobacco Manufacturing industrial plant, which defines the entire complex as a closed citadel.

The final shape of the area, as it appeared at the times of the competition, was due to various later processes of abandoning and demolition caused by unfinished disembowelments provided for by the Regulatory Plan of 1889 and by the bombing of the Allies during World War II.

Finally, after the war the neighbourhood was characterized in the Reconstruction Plan as service area where it built the Indoor Sport Arena, located at the crossroads of Via Lame and Via Riva di Reno, and a relevant instruction structure, while the private residential edification generated highly crowded buildings around. Significant to note that, although the area has increased its services and activities until today ${ }^{5}$ of territorial level those make it used and vital, it conserves this fragmentary aspect and, crowned by tall buildings and surrounded by major traffic arteries, the character of an enclosed area to be discovered, still remains.

The competition of ideas, launched by the Bologna Municipality in 1984, was developed in two stages, an interesting procedure, albeit unconventional, chosen in other urban contests $^{6}$. There were 138 participants ${ }^{7}$ in the first stage to which is required to apply a curriculum vitae and an illustrated dossier with the architectural designing program for the area. The jury panel consisted of members of the Public Administration and important figures such as, among others, Roberto Gabetti, Paolo Portoghesi and Umberto Eco; in the second phase they chose 15 projects and asked each of the chosen groups to develop in details the proposal. Projects submitted focused on the park and its contradictions too small for a real urban park, too big for being a garden; furthermore, the competition specifically addressed: the development of cultural structures, sport and social facilities, natural environment, the restoration and re-functionalization of the former Tobacco Warehouse and of the others buildings, and more, the planning of new buildings and parking lots.

Starting from these requests and the state of the area, the designing of a new part of the city became the chance to work on architectural fragments, aiming at composing a new harmonious and uniform organism, paradoxically offered from the total lack of attractivity, as previously described.

As will be seen in detail in the following description, the solution proposed by Quaroni's group, composed by Aldo Aymonino and other young architects from Bologna Giampiero Cuppini, Stefano Piazzi, Claudia De Lorenzi, Stefano Sarti, Luigi Tundo, Claudio Baldisseri, Giuseppe Cicognani - was established on some aspects such as: the reflection about the tangible dimension of the area, the value of the traces of the past, its relation with historic town center, the role of the drawing as an instrument of re-composition and, at the final, the specific meaning given by Quaroni to the public content. Precisely in relation to these aspects, the project for the Tobacco Manufacturing is fully coherent with Quaroni's whole production, including works very different among themselves such as the Tiburtino neighbourhood (1954 realization), the competition 
project for the residential complex in the Barene of San Giuliano in Venice (1959) or the macro-structures of the Sixties and of the Seventies.

The common driver of the architectural production is, in fact, the research, lead with different instruments and methods, of an unitarily tendency according to the original principle of the city: a city that is considered as an art work, as a "marvelous" (Quaroni, 1967: 144) ${ }^{8}$ and utopic city from the past, when the urban structures were clear and unified.

The same clarity of the plan can be obtained, in the new project, with a design highly readable and recognisable. Design is at the same time the outcome and the instrument of the investigation (to be understood in the meaning of drawing), as Quaroni himself states many times in his theoretical production and also in practice. The architect thus makes immediately clear his intention of obtaining a clear framework: "Quaroni's design was already made" (Stefano Piazzi, interview, April 30, 20I4). Nevertheless, the design does not generate a sign, which integrate landscape, architecture and functions, differently from roman architect's previous works, such as the project for Rome Office District (1967). In Bologna, after almost twenty years, the purpose of the design is more focused on building an image and defining the relationship between singular parts in the area and between the area itself and the city, always in an autonomous status.

Through this methodological way, and not as a conservative one, the project purposes the aim of the urban regeneration, to be understood as a figurative-regeneration. "We thought that the chance was too important, and that the relicts were too disarticulated and casual to be taken in consideration" (Vincenzi, Veggetti, Zanna, 1985: 392). It meant that the traces from the past were too weak to induce a conservative approach", which was chosen just for some remnants: the bakery, the building of the Salt Warehouse, the former Slaughterhouse and the 19century hangars.

In fact, in the preliminary draft submitted for the first stage of the competition substantially unchanged in the second phase - the projects consisted in an articulations of figures: geometrical elements chained one to the other in a string that goes from Via Riva di Reno to Via Pietramellara, crossing the space and connecting the Tobacco Manufacturing front with the industrial buildings that needed to be conserved. This progression of forms is obtained with basic shapes: the square for the Museum plaza; the circle for the space where to plant trees; the triangle that should host the herbs garden; the long straight body of the artisan shops, parallel to the triangle side that defines the north-western front of the creek.

In order to recover the water elements previously part of the area, the project aims to rebuild the waterfall of the Cavaticcio: it would flow into the rebuilt dockyard, on which western side rests the headboard of the building of the artisan's shops. The northwestern side, instead, is defined by a body of residential buildings.

The oriental prospective is defined by a colonnade with the typical shape of Bologna porticos; the other side is characterised by a series of bodies disposed in comb-like rows in respect of the main body, that face the irregularity of buildings on that side. Finally, the volumes of the former Salt Warehouse, of the bakery, of the storehouses and of the plants along Don Minzoni Street are restored for a functional usage, keeping their shapes and volumes.

The project shows furthermore that the figures design internal spaces defined by fences or excavations, so it works on the void. 
It is interesting to note how the theme of the empty spaces is actualised when the growth in population number in those years urged a consequent need of green areas and free sports, such the ones above described; void (Silvia Morselli, interview, April 30, 20I4) became therefore necessary and defined the whole life of the area even before of the competition.

The occupation of the central area - an approach chosen by most solutions submitted to the competition - is here opposed by the idea of building on the perimeter, a "lining"

(fodera in Italian) as Quaroni himself called it (Vincenzi, Veggetti, Zanna, 1985, vol.I: 477), made up mostly by the fronts of existing buildings by a new body of residential buildings and by simple walls surfaces to be built, together with frameworks for plant-growing. The "lining" represents the architectonic curtain of the rear of the park and must be therefore studied with a particular attention (notably, Quaroni himself draws the views), in order to recall the traditional city architecture made of exposed bricks. The outcome is a contrast from the popular language and the noble intellectual codes of the design drawing. The idea of having an harmonious front facing the urban variety - here perfectly represented internally by the variety of the park and externally by the borders of the city - is considered by Quaroni innate in Bologna, traceable in the long running porticos in front of the houses or in the facade of the Palazzo dei Banchi in the city major square. This reminiscence of an urban historical image of the city (later this fundamental aspect will be more thorough) make those abstract shapes real facts, not only signs.

This is also possible reserving great attention in the project at the intersections of the forms in the plan with the city lay out. The project focuses, for instance, on the continuity of the axis that connects Largo Caduti sul Lavoro with the area of the Indoor Sport Arena, proposing a path similar to that of the "rambla" and putting in this spot the ramps to descend to the parking.

The trees fence somehow becomes the junction point of the path, already included in the I 889 Bologna Regulatory Plan as part of the wider connection between Lame and Marconi streets - nowadays useless because of the existence of the block confining with Castellaccio street ${ }^{10}$. Furthermore, in the project, the reopened canal can be crossed through a bridge, located on the extension of Marghera Street. The will of a seamless unity with the existing urban texture is shown as well in the recovery of historical bodies: the building of the Tobacco Manufacturing on Riva di Reno Street becomes the filter between the park and the city, while the former Slaughterhouse is the element that drives the structuring to the area around Lame gate.

The connection among the parts of the city - through the proper positioning of the new bodies - permits to give a personal interpretation to term of "conservation", in this case related to the urban texture. This approach is very far from the one of the previous and parallel intervention in Bologna historical centre done by the Municipality following the Cervellati's Plan, naturally to be compared.

Quaroni's group project is not based in fact on morphological and typological investigation searching for founding matrix for the new intervention. Nor does it base the planning on the integration of the pre-existing elements. "A roman outcome" (Stefano Piazzi, interview, 30.04.20I4: referring to contemporary searches of other architects coming from the school of Rome, such as Carlo Aymonino" or Costantino Dardi). A new image made of universal types: the square, the "Rotonda", the wood. Nor "formal synthesis nor assembly" (Terranova, 1985: $3 \mathrm{I}$ ), nor overlapping as in a collage, as seen in some works of Colin Rowe or James Stirling. 
The project is not either a mere composition based on analogical principles such those of Aldo Rossi - an author that is however important to recall, because of his ties with Quaroni and particularly with the project for the Tobacco Manufacturing.

In 1993, Aldo Rossi's project refers to "a composition with city elements" to form a big urban architecture, in spite of just a single episode - that in his views gives the idea of the city magnificence. Rossi's starting point is therefore close to the one of Quaroni, especially in his usage of the types of the historical city to compose, through single architectures, a new organism measurable with the scale of the city. The outcomes of Rossi's project are very different those from Quaroni, that presents a centrality of issues like memory and urban scale, both strictly connected.

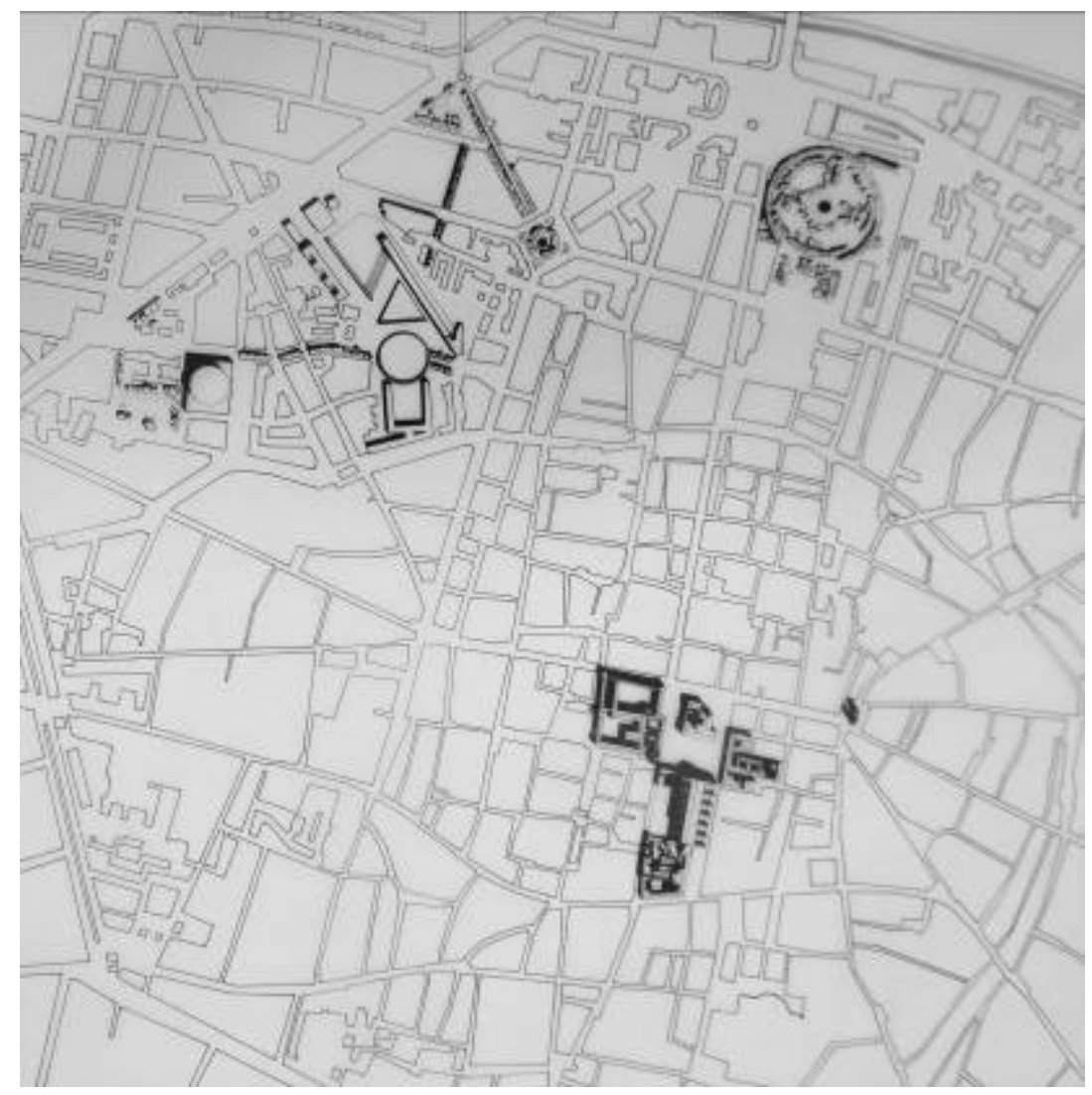

Figure I. Drawing of competition. New project vs old town.

(Courtesy of Stefano Piazzi architect. Aspilt Studio, Bologna).

Continuing to discuss our author's proposal, in the formal approach previously explained, made of geometry and rigors, Quaroni is inspired not only from the ancient city, but also from a 19century manner to search a clarity of the urban texture, such that of the Italian towns after the Unity in 186I, that would also affect the area object of the Plan of I889 to be completed. Similarly to the XIX century city, the project gives the idea of an urban complex designed at the same time empirically and concretely, in particular looking for the correct measure for this shapes.

In the fringed borders of the area, "finding a size" (Stefano Piazzi, interview, April 30, 2014) becomes a methodological fact and a reason for the whole intervention. 
Following an analysis driven for "progressive genres" (generi scalar in Italian) ${ }^{14}$, as Quaroni himself called it many times (see for instance Terranova, 1985: 22), the new design seems to communicate the idea of an overall consistent with the size of the city that could be seen from distance at the scale I:5000, as shown in the plan of the competition (Fig. I). The urban appearance of the new part of the city can be assimilated in particular to the size of other public places of the historic city as Major Square and the Montagnola Park. Getting close to scale 1:500 (Fig. 2), instead, the dimension of the designed figures show its autonomy.

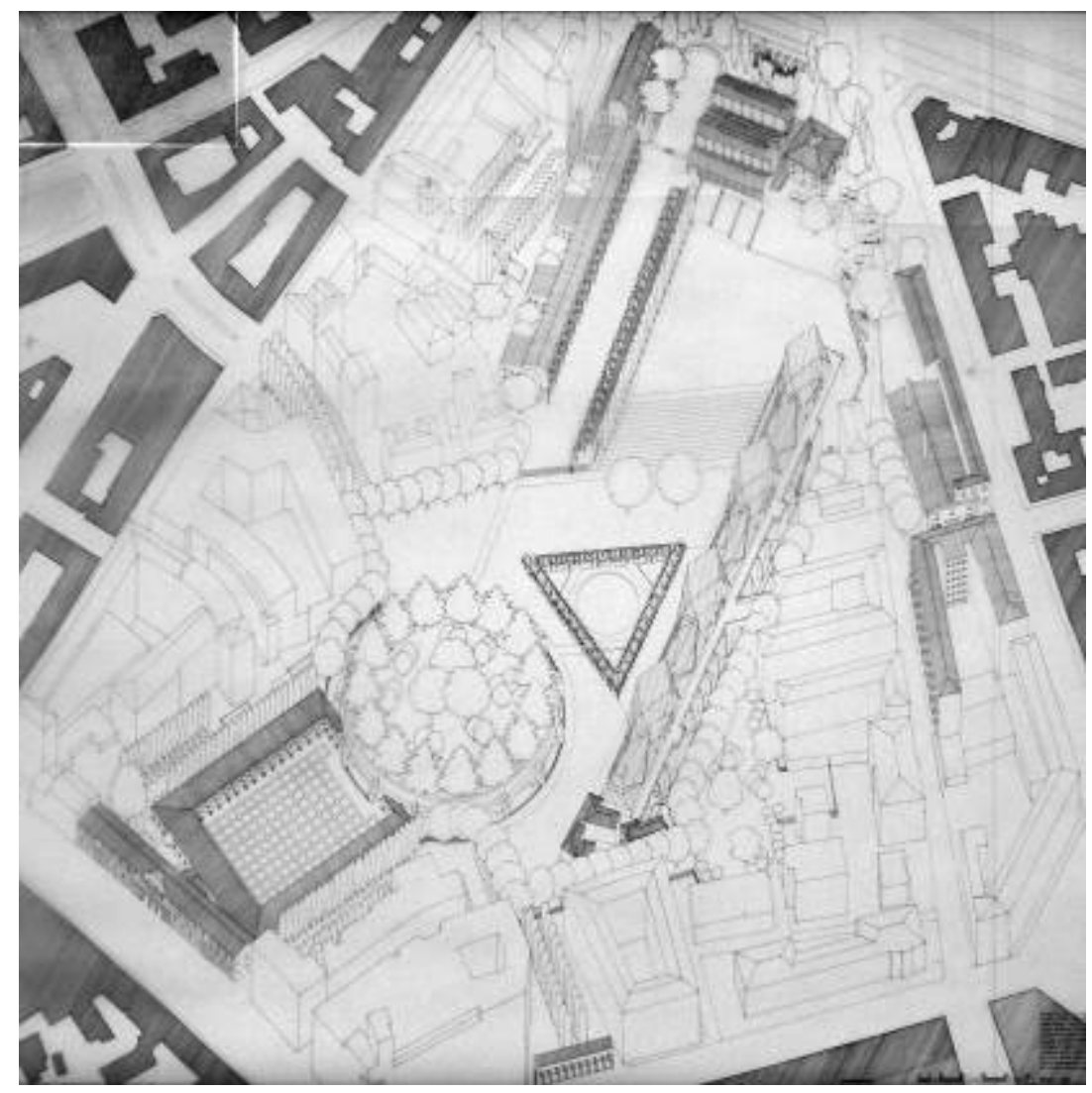

Fig. 2. Competition drawing. Axonometric view of the project.

(Courtesy of Stefano Piazzi architect. Aspilt Studio, Bologna).

So the plan has to be read on two different layers: one uses sizes that are proportional to the city scale; the other uses sizes proportional to the extension of the area (8 hectares) "evocative" of an unit of measurement belonging to the chosen architect staff imaginary. The memory, for instance, of some "patrician villas of Northern Italy" that give the "intermediate" size "between that of the park and those of the gardens with a $19^{\text {th }}$ Century style" ("newly 19th century”, Vincenzi, Veggetti, Zanna, 1985: 392); solving the ambiguity of dimensions previously mentioned.

Sizes therefore, does not refer here to something already existing in that same place - if there is any connection, it should be with the gardens existing in the area from the Middle Age - but measurements rather recall universal objects from architecture history, believed able to respond to some instances of the project. The contextualisation is therefore to be seen as "extracting from a place its will of shape, unique, although 
through an interpretation that can be deeply modifying" (Terranova, 1985: 31). In a similar way, the reference to a picturesque garden results useful to reach an integration between building and green spaces, and communicating an idea of nature if there is not any previous example in this part of the city.

This cultural reference become practical guidelines in design, seen in the recovery of the late-sixteenth century principle to let plants grow without pruning, updated to contemporary knowledge that harness the greater variety of known species.

The dialogue - or the "symbiosis", as Quaroni himself calls with an organicist reference between nature and buildings goes on along the perimeter as well, on that "lining" (fodera in Italian), differently this time from the historic sub-urban villas.

The idea of space, its suggestions and instruments, always come from history, adapted to the place and to the present times. Quaroni states in his lessons ${ }^{15}$ that the image of a building is not a model, but rather a combination of influences. He also says that the image can be inferred from other shapes belonging to other times, changing their final purpose while keeping the same marks - a process that relate to technological progress as well.

Historic city provides at the same time evocation and unit of measurement.

It is clear that it is a completely different approach from the search of a postmodernist style.

A last theme that emerges reconsidering this important design and debate occasion, concerns the value attributed to idea of "public", still deriving from the Quaroni's continuous swinging between the real and the imagination ${ }^{16}$ as the fundamentals of architecture that interest also the functionality of buildings and spaces.

Similarly to the double-layer scale of dimensions, the range of activities in the area of the project is thought both at a neighborhood and an urban-territorial level.

In the first stage of the competition, the functional program (indicated by contenders rather than by the Municipality) figures a "museum square" in the four-sided portico: it is a series of little places for the botanizing plants variously organised and where exhibition of Natural History should be held. Those places should be stirred with "very little museums" (Vincenzi, Veggetti, Zanna, 1985, vol. I: 476) where everyday crops and handcraft should be shown, together with the techniques to produce them. The circular fence is thought for growing trees, while the triangle should be filled with grass and herbs, as those of the ancient monasteries of the area, once again connecting a generic reference with a specific one. The former Slaughterhouse and the Salt Warehouse would become places for indoor sport activities, fulfilling the desire of facilities for spare time and combining it with the historical vocation of the place.

The project also figured a planning of events and activities, from shows to educational programs, for youth and kids - a planning guaranteed by the involvement of the Municipality institutions in the management of the area on the model of the "Vallée de la Jeunesse" in Lausanne (1964). The area should also offer daily services and functionalities for those living nearby: elderlies, women with children and youth.

The plan does not undergo major changes in the second stage; nevertheless, the final proposal redefines some functional aspects. The Manufacturing building, for instance, become an info-point in direct connection with the four-sided portico - that instead remains the place of little museums of handcrafts and materials where youth could learn their art from the older artisans. 
The courtyard surrounded by porticos allows activities to be mixed up, divided between ground and first floor, between east, west and north wings, underlining the multiplefunctions of basic geometrical shapes. The inside of the courtyard, overawed by a big potted orange plant, should host concerts and open air shows for the youth. The Rotonda, a big thick walled fence opened on ground floor by arcades, is the junction point of the complex characterised by "tall trees", while the Nymphs triangle is thought for intimate and lonely walks. Its perimeter is made of a 'berceau', a portico with barrel vault covered on one side with climbing plant recalls Mediterranean gardens, and extended in a wisteria portico, located in front of the houses; the two elements together build a piece of the urban street that keeps a strong sense of nature nonetheless.

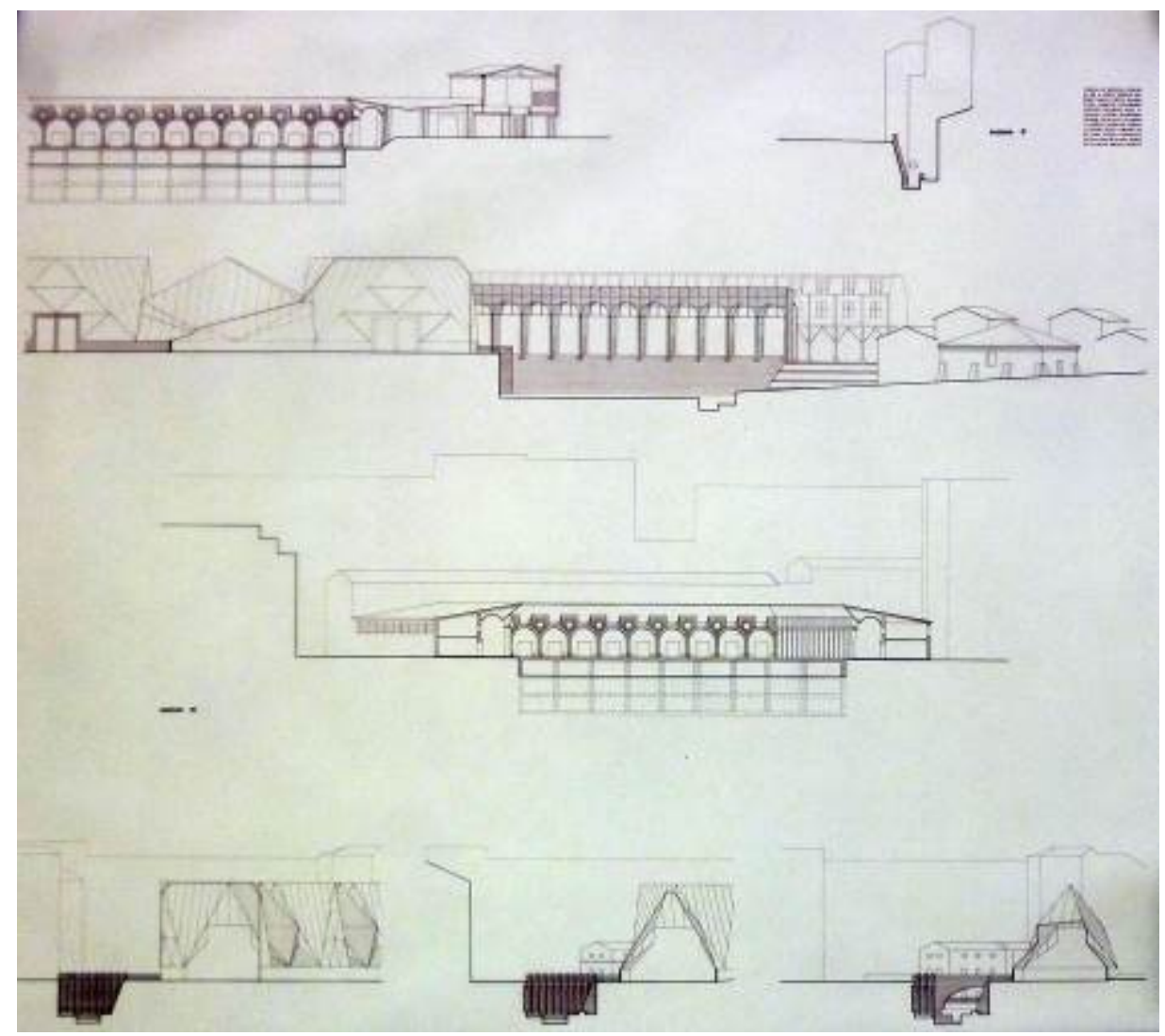

Fig. 3. Drawing of competition. Sections on "Serra", "Darsena" and "Quadriportico". (Courtesy of Stefano Piazzi architect. Aspilt Studio, Bologna).

The real new element though, is the Greenhouse replacing the artisans' shops, which arose in the second stage of the project. It is made from a sequence of eight windowmodules shaped as Archimede's cuboctahedron polyhedron, an image of a big geometric exercise, tridimensional, multifaceted and transparent, a clear reference to the glass architecture of Paul Sherbart as underlined by Paolo Portoghesi (Vincenzi, Veggetti, Zanna, 1985: II) and to "the elegance of some vegetable forms", as say the same Ludovico Quaroni (Vincenzi, Veggetti, Zanna, 1985: 392).

The lightness of this glass Greenhouse is balanced by the mighty arcade walls on the opposite side of the canal, in a continuous alternation from lightness to solidity, of nature and artificiality (Fig. 3). Inside, some sectors are freely walkable; some others are service 
areas for the park while an independent cafeteria is located in the headboard of the dockyard. The rest is occupied by a Vegetable museum. In this space, the fragmentation of the sectors also allows a variety of uses of the linear body. Industrial buildings located north are kept and intended for sport and fun activities. The bakery hosts "The motion house" with gyms and theatres; the hangars of the former Slaughterhouse become the place for restaurants and bars. Behind those should then raise the "Walls theatre" and the skating rink, while the former Salt Warehouse (Fig. 4) should host a centre for elderlies, with areas for consulting papers and videos and exhibitions.

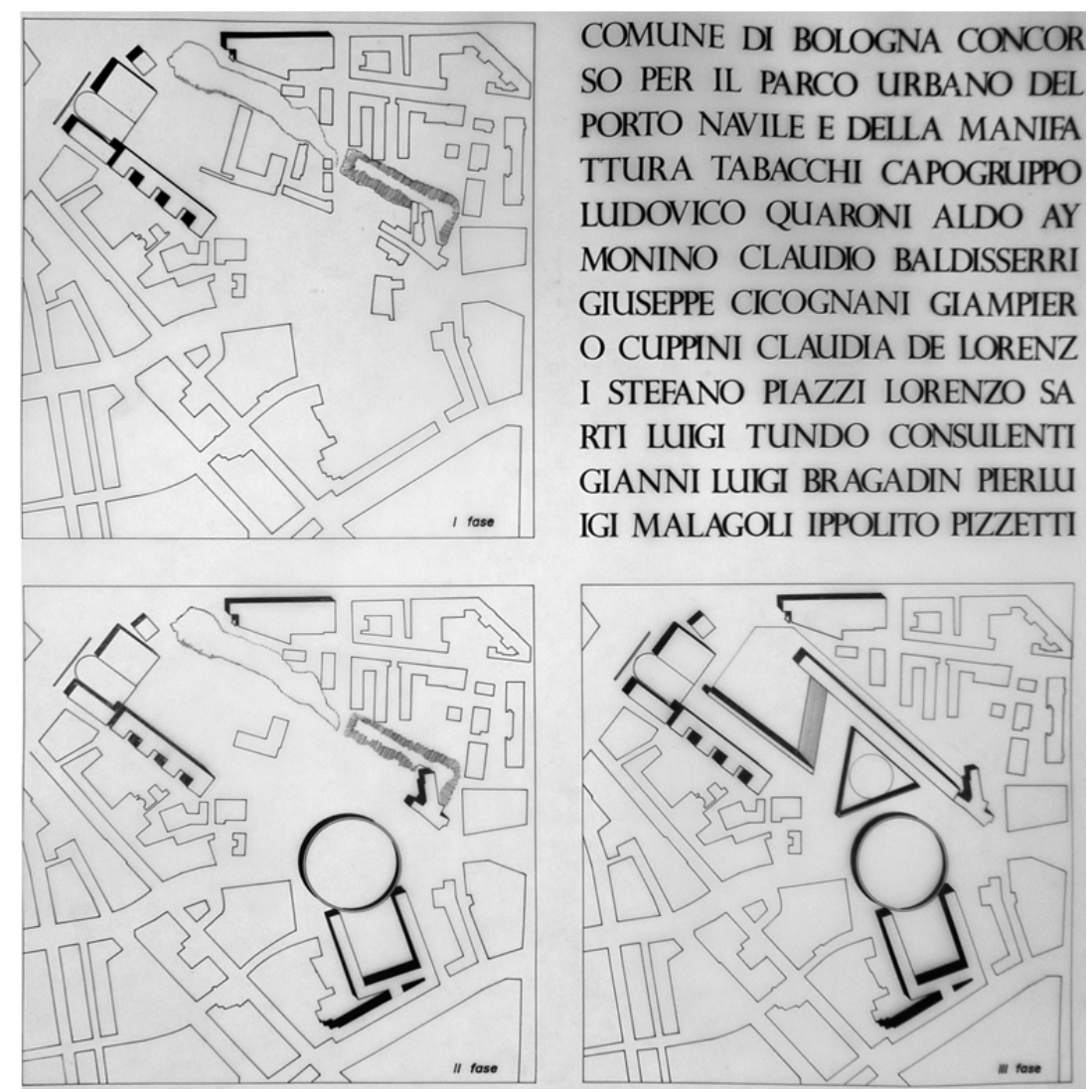

Figure 4. Competition drawing. Phases of the realisation.

(Courtesy of Stefano Piazzi architect. Aspilt Studio, Bologna).

The actual dimension of the project lies in thinking as well at the managing aspects of the process, which implies thinking of everything that comes after, not only for users (Quaroni, 1977). Hence the indication on a multi-phase realisation of the different structures composing the project (Fig. 4). First, should come the building of the houses and the recovery of the bakery, of the Salt Warehouse (Fig. 5) and of the hangars. Then, in a second phase, the renovation of the Tobacco Manufacturing building, the making of the four-sided portico; last, the Greenhouse. To sum up, the project shapes model both a "tangible city" "17 and the spaces of a "city for human".

Purposes become life, places have names and well-defined users; it's possible to know at What time of the day or of the year any place should be used and what its relation is with other parts of the city and with the city institutions, as Umberto Eco tries describing the 
project taking the side of the citizen (Vincenzi, Veggetti, Zanna, 1985, vol.I: 29-32), imaging which activities and what kind of life could be developed in the area.

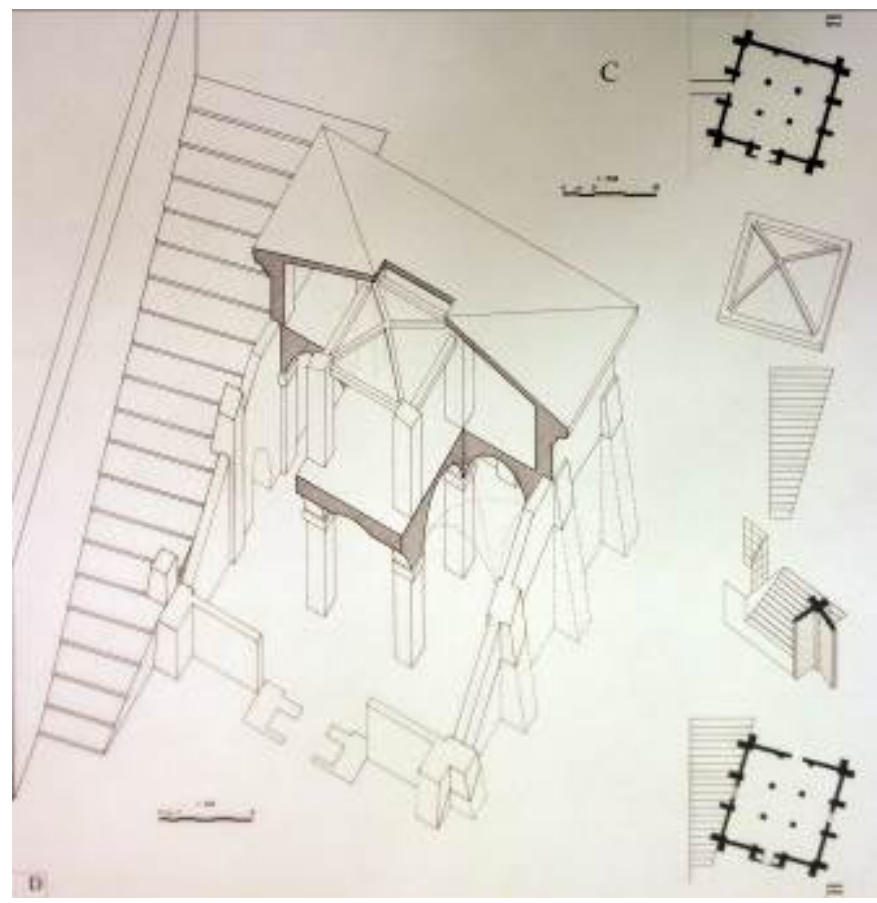

Fig. 5. Competition drawing. Project of the restoration of the former Salt Warehouse. (Courtesy of Stefano Piazzi architect. Aspilt Studio, Bologna).

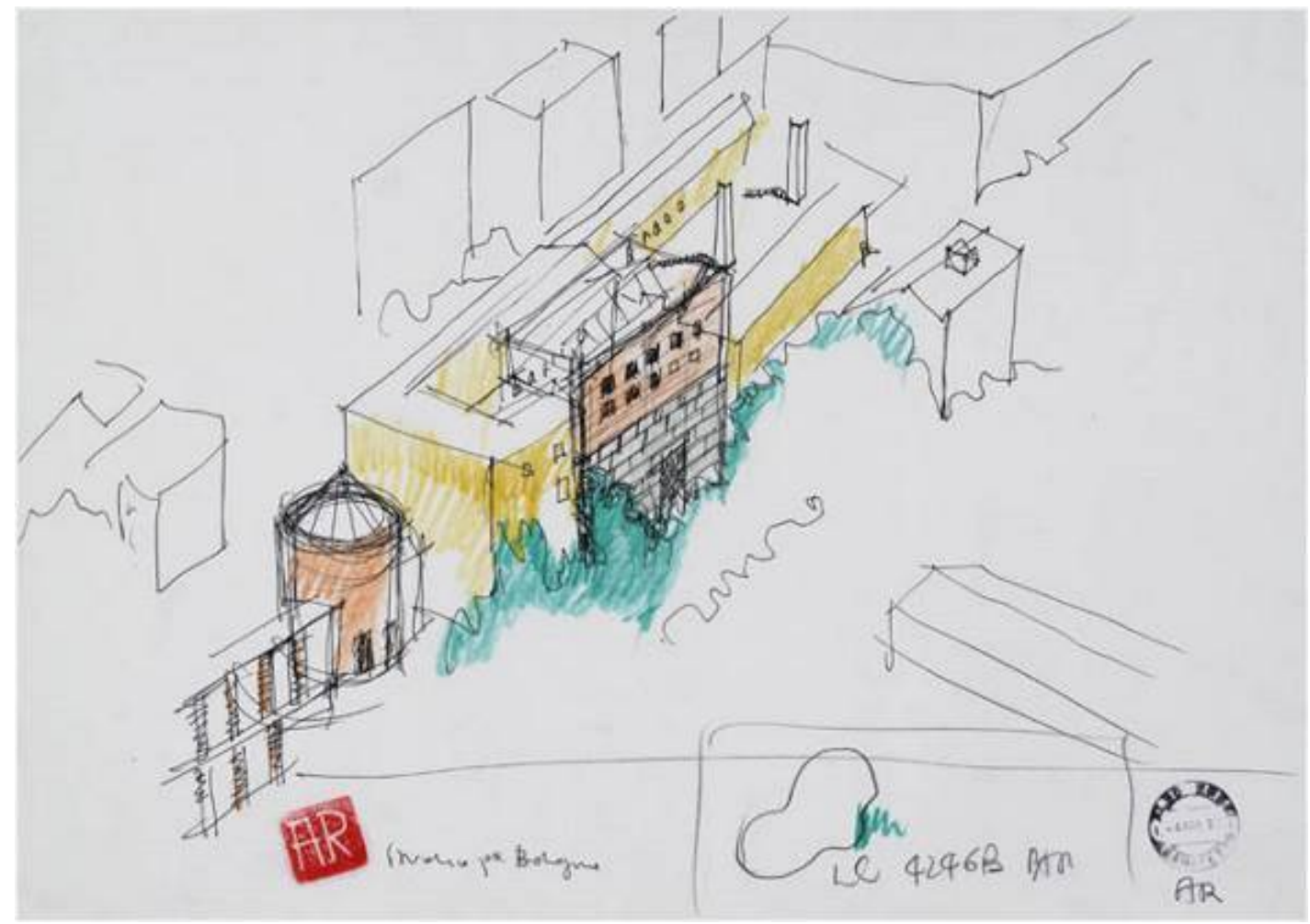

Fig. 6. Aldo Rossi's drawing for the new project.

(C) Eredi Aldo Rossi, Courtesy of Fondazione Aldo Rossi). 
This makes obvious the collective dimension of an imagination that is at time evocative and tangible, comparable with the rest of the city, precisely what is thought to be the correct interpretation of public value of the project.

The architect seems to try to make real what he had previously often written about the historic city (Quaroni, 198I: 264). The importance and the interest both in the private and in the public sphere have to be wide and extended never constricted in mere individualism the first and in ideology the latter. Doing so, the compenetration of the two spheres makes the city, or at least a part of it, harmonious and balanced.

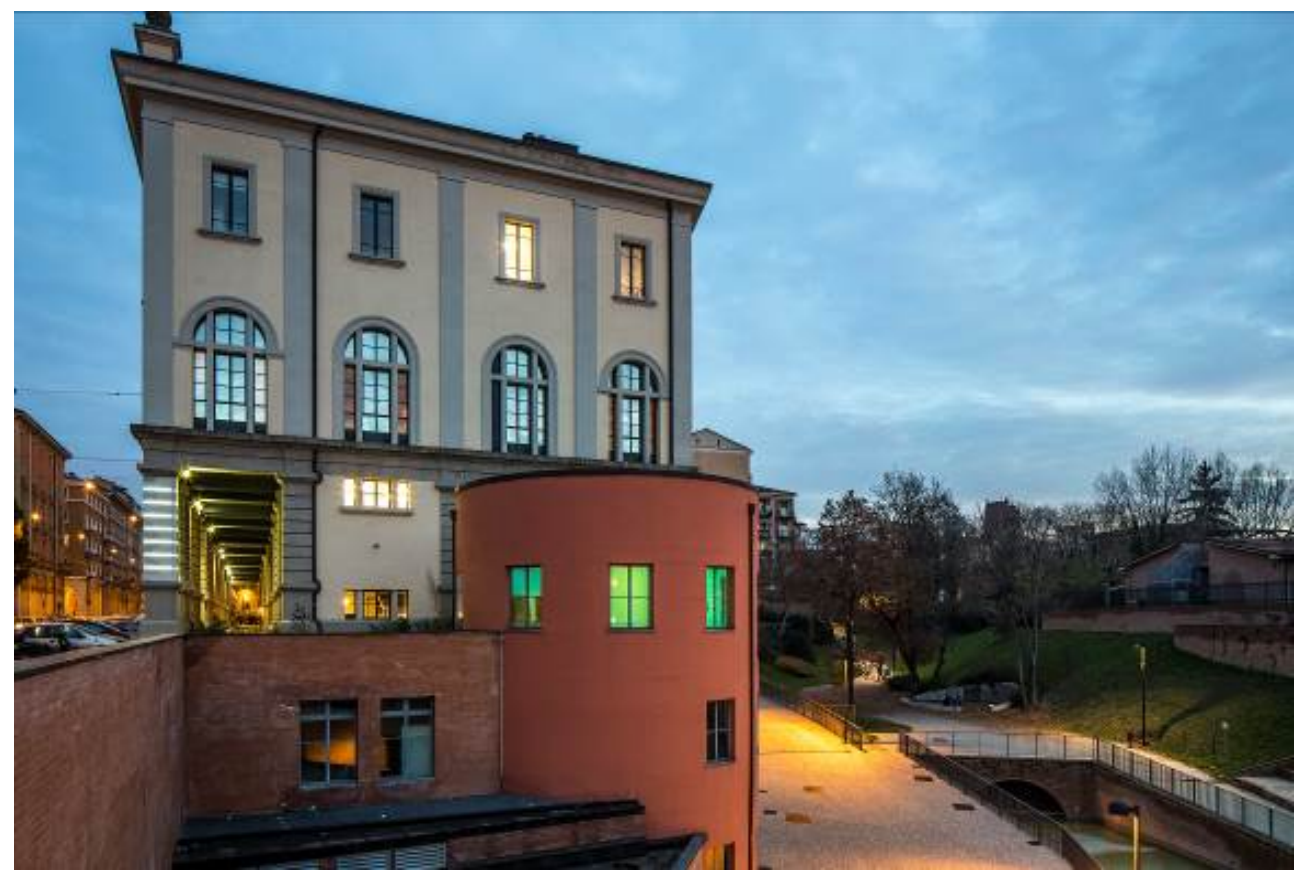

Fig. 7. The Navile Park in Bologna today. View from the entrance of Mambo Museum. (Courtesy of Fabio Mantovani photographer).

\section{Acknowledgements}

The author would like to thank architects Stefano Piazzi and Silvia Morselli for the interesting talk about the history of the competition and for the drawings provided.

\section{Notes}

(I) See the registers of the fundamental biography on the author, such as Ciorra (1989: 168), that provides other works from Quaroni, useful to strike a balance of the author's overall production. See also Quaroni, II mio modo di essere architetto, in Terranova (1985).

(2) We are referring to the enlargement of the cemetery in Sasso Marconi. See G. Gresleri (1987), Ultima lettera a Quaroni, in Parametro, 156, p. 2.

(3) A "joke-project" regarded by Bruno Zevi as part of the senile work of the architect, recognized by Quaroni himself as a mature project. Zevi's comment and Quaroni's following reflections are covered in 'Parole agli studenti di Ludovico Quaroni', Domus 689, p. 12.

(4) The point has been investigated by M. Zardini (Vincenzi, Veggetti, Zanna, 1985: 26), who underlined the different methodological approaches emerged from the projects that reached the second stage of the competition. Such a methodological variety, according to Zardini, 
highlights both the richness of the architectural research at the time and the difficulties in dealing with the new urban binding. In the same text $G$. Campos Venuti points out how such way of investigation became a morphological inquiry, that can be traced in the new regulatory plan of Bologna (Gli scandali sono necessari, p. 27).

(5) See footnotes number 13.

(6) See comments from Roberto Gabetti (Vincenzi, Veggetti, Zanna, 1985, vol. 2: 33-35) and Giorgio Trebbi (same text: 445-476). The competition was considered at its conclusion as a good chance for an investigation on the city; this evaluation, though, changed radically given the following circumstances. A report, ten years after the end of the competition, was given by Alemagna, Bottino (1994). The final outcome of the project for the Tobacco Manufacturing with its long history - remarks from the Superintendence, the drop out of Quaroni's project, the draft of project from the Municipality and the final appointment of architect Aldo Rossi, left out from the first stage of the competition - testify the continuous uncertainty of such competitions, despite good preconditions.

(7) All of most important architects of the time enrolled in the competition. Among most famous groups, those of Costantino Dardi, Aldo Rossi, Ignazio Gardella, Leonardo Benevolo, Vittorio De Feo, Gianfranco Caniggia, Andrea Branzi, Franco Purini, Marco Porta, Carlo Melograni, Alessandro Anselmi, Adolfo Natalini, Ugo La Pietra. Groups that reached the second stage of the competition were those of: Anselmi, Battisti, Benevolo, Ghio, Ferrara, Gardella, Billi, Caniggia, Dezzi Bardeschi, Mazzini, Nicoletti, Pastore, La Pietra, Purini e Quaroni. The groups of Capobianco, Chiodini, Cinti, Dall'Erba, Ricci, De Pas, Gabrielli, Lenci, Melograni, Natalini, Roggero, Sironi deserved instead a mention from the jury panel.

(8) Quaroni's reflection on this aspect, although less ideological, remain the utopic contents of the previous decade until the end of the Seventies (a time close to the Tobacco Manufacturing project). These utopic aspects are among the most interesting in the theoretical production of Quaroni. M. Tafuri (1964: 15) acknowledges that his continuous methodological experimentation is firmly opposed to the ideological stillness of other works of that time.

(9) It is important to underline how the requirements of competition cleared that a conservative approach was not needed for the urban renovation - orienting therefore the choices of Quaroni's winning project. Nevertheless, the lack of a conservative approach became afterwards an obstacle to the realization of the project itself, causing at the end its discard. Stefano Piazzi recalls how Quaroni's group later tried to adapt the project to the remarks of the Superintendence (the updated project can be found in the Stefano Piazzi's archive in Bologna). Nevertheless, the nature itself of the project was so uniform that later adjustments were very hard to introduce. See also Alemagna, Bottino (1994).

(10) A need that is still actual, as pointed out by architects Silvia Morselli and Stefano Piazzi (Interview, April 30, 2014).

(II) See C. Aymonino (1988). Piazze d'Italia. Progettare gli spazi aperti. Milano, Electa.

(12) Due to the discard of the winner project, that of Quaroni's group, Aldo Rossi is asked to design a project for the area to transform it in a cultural pole. See A. Ferlenga (1999). Aldo Rossi. Opera completa II. 1988-1992, Milano, Electa, Pp. I28-131. The project focused on the northern part of the area and intervened on existing buildings. Aldo Rossi held just a super visioning role and the project was effectively made by Bologna Municipality Office, on the occasion of the moving of some important museums of the city (Gam, Morandi), universities (Communication Sciences Department) and cultural centres (the library of the Cineteca of Bologna and the Lumiere cinema). In 201 I the Cavaticcio park was also completed.

(13) In the preface of Ludovico Quaroni's book, La torre di Babele (1967: 16), Aldo Rossi wrote a comment that appears useful in approaching this project: "This project of a modern city (the one that Quaroni is describing in the six essays of the volume), made of parts and monuments seamed in a homogeneous design, all planned in its multiform aspects where - as 
in every collective event - personalities with their experience and myths are to emerge represents an alternative, an alternative to ugliness, to short-sightedness, to exploitation, to any kind of limits of our cities" (translation from Italian to English by the author).

(14) Quaroni developed seven scales of intervention, from the design of settlements for $50-100$ inhabitants to the regional and national planning. Each one is tied with the other six ones through integrated scales of intermediate design: architectural, micro-urbanistic, urbanistic, district, regional, national (Quaroni, 1996: 148 - translation from Italian to English by the author).

(I5) Ibidem.

(16) See, among Quaroni's last works, the proposal for Rome presented on the occasion of the XVII Triennale of Milan, with the meaningful title Le citta immaginate. Un viaggio in Italia. Nove progetti per nove città. The project works on the image of the historic city, transforming the Vittoriano in a ruin, deprived of its monumental idea and its celebrative function, but re-given to the citizen through a new use.

(17) Quaroni deals with this subject in various occasions. Precisely, the architect considers the term "city" as indicating three things: the social-urban structure, the urban-tangible structure and the overlapping of the two - a difference between the classical separation between "urbs" and "civitas" (Quaroni, 1996 - translation from Italian to English by the author).

\section{References}

Gabetti R, Quaroni L. (1985). Bologna: il concorso per il parco urbano della Manifattura Tabacchi e del porto Navile: il progetto vincente di Ludovico Quaroni, in Urbanistica, 79, pp. I I 2-I 23.

Vincenzi S., Veggetti E., Zanna M. (1985). II labirinto. Centrotrentotto idee progettuali per il parco urbano del Porto Navile e della Manifattura Tabacchi. Catalogue of the exhibition promoted by the Municipality of Bologna (I \& II volume.). Casalecchio di Reno: Grafis.

Alemagna, V., Bottino C. (1994). Bologna: è finito il concorso per l'ex manifattura tabacchi?, in Urbanistica, 135, pp. 36-38.

Brigi, E., Magnani, M. (1992). Bologna, ancora sull'area della Manifattura tabacchi, in Parametro: bimestrale di architettura e urbanistica, 192, pp. 6-7.

Ciorra, G. (1989). Ludovico Quaroni. 191 I-1987. Milano: Electa.

Dal Co, F. (1987). Ludovico Quaroni, I9II I 1987. Domus, 689, pp. I4-I7.

Montuori, M. (1994), 10 maestri dell'architettura italiana. Chapter on Ludovico Quaroni, Milano,

Electa, pp. 182-217.

Orlandi, A. (1987). Ludovico Quaroni: dieci quesiti e cinque progetti. Roma: Officina.

Piccini, M. (1996). Temi dell'urbanistica bolognese dieci anni dopo il piano. Urbanistica informazioni: supplemento bimestrale di Urbanistica: rivista dell'Istituto nazionale di urbanistica, 14, pp. 25-27.

Quaroni, L. (1967). La torre di Babele. Venezia: Marsilio editore.

Quaroni, L. (198I). La città fisica. Bari-Roma: Laterza editore.

Quaroni, L. (1977). Progettare un edificio. Otto lezioni di architettura. Milano: Mazzotta editore.

Quaroni, L. (1996). II progetto per la città: dieci lezioni. Roma: Kappa.

Tafuri, M. (1964). Ludovico Quaroni e lo sviluppo dell'architettura moderna in Italia. Torino: Comunità. Terranova, A. (1985). Ludovico Quaroni. Architetture per cinquant'anni, Roma: Gangemi editore.

Zardini, M. (1985). Bologna: un vuoto urbano, in Casabella, 5I2, pp. 20-3I. 